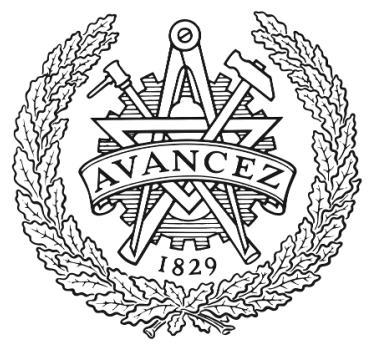

CHALMERS

UNIVERSITY OF TECHNOLOGY

\title{
Enriched microbial communities for ammonium and nitrite removal from recirculating aquaculture systems
}

Downloaded from: https://research.chalmers.se, 2023-04-26 12:27 UTC

Citation for the original published paper (version of record):

Neissi, A., Rafiee, G., Rahimi, S. et al (2022). Enriched microbial communities for ammonium and nitrite removal from recirculating aquaculture

systems. Chemosphere, 295. http://dx.doi.org/10.1016/j.chemosphere.2022.133811

N.B. When citing this work, cite the original published paper. 


\title{
Enriched microbial communities for ammonium and nitrite removal from recirculating aquaculture systems
}

\author{
Alireza Neissi ${ }^{\text {a }}$, Gholamreza Rafiee ${ }^{\text {b, }}$, Shadi Rahimi ${ }^{\text {c, }}{ }^{* * *}$, Hamid Farahmand $^{\mathrm{b}}$, \\ Santosh Pandit ${ }^{\mathrm{c}}$, Ivan Mijakovic ${ }^{\mathrm{c}, \mathrm{d}, \text {, }}$ \\ ${ }^{a}$ Nuclear Agricultural School, Nuclear Science and Technology Research Institute, 31465/1498, Karaj, Iran \\ ${ }^{\mathrm{b}}$ Department of Fisheries Sciences, Faculty of Natural Resources, University of Tehran, 331585-4314, Karaj, Iran \\ ${ }^{\mathrm{c}}$ Chalmers University of Technology, Division of Systems \& Synthetic Biology, Department of Biology and Biological Engineering, Kemivägen 10, 41296, Gothenburg, \\ Sweden \\ ${ }^{\mathrm{d}}$ Novo Nordisk Foundation Center for Biosustainability, Technical University of Denmark, 2800, Lyngby, Denmark
}

\section{H I G H L I G H T S}

- AOB and NOB bacteria were enriched in selected microbiomes.

- $N$. oligotropha and N. winogradskyi were the highest portion of microbiomes.

- The microbiomes removed ammonium and nitrite at different temperatures.

- Microbiomes significantly removed ammonium and nitrite from RAS biofilter.
G R A P H I C A L A B S T R A C T

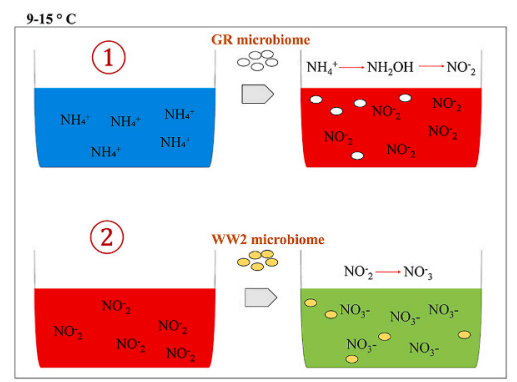

\section{A R T I C L E I N F O}

Handling Editor: Dr Y Yeomin Yoon

\section{Keywords:}

AOB and NOB Microbiome enrichment

Nitrosomonas oligotropha

Nitrobacter winogradskyi

Temperature adaptation

Aquaculture biofilter water

\begin{abstract}
A B S T R A C T
The aim of this study was the enrichment of high-performance microbial communities in biofilters for removal of ammonium and nitrite from aquaculture water. Ammonium oxidizing bacteria (AOB) and nitrite oxidizing bacteria (NOB) were enriched from different environmental water samples. The microbial communities with higher ammonium and nitrite removal activity were selected and adapted to different temperatures $\left[9^{\circ} \mathrm{C}, 15^{\circ} \mathrm{C}\right.$, room temperature $\left(25{ }^{\circ} \mathrm{C}\right)$, and $30^{\circ} \mathrm{C}$ ]. The expression of genes involved in nitrification including ammonia monooxygenase (AMO) and nitrite oxidoreductase (NXR) were measured in temperature-adapted AOB and NOB microbiomes. The microbial species present in the selected microbiomes were identified via 16s rRNA sequencing. The microbial communities containing Nitrosomonas oligotropha and Nitrobacter winogradskyi showed the highest ammonium and nitrite removal activity at all temperatures used for adaptation. Furthermore, the microbial communities do not contain any pathogenic bacteria. They also exhibited the highest expression of AMO and NXR genes. Using the enriched microbial communities, we achieved a $288 \%$ and $181 \%$ improvement in ammonium and nitrite removal over the commonly used communities in biofilters at $9{ }^{\circ} \mathrm{C}$, respectively. These
\end{abstract}

\footnotetext{
* Corresponding author. Chalmers University of Technology, Division of Systems \& Synthetic Biology, Department of Biology and Biological Engineering, Kemivägen 10, 41296, Gothenburg, Sweden.

** Corresponding author.

$* * *$ Corresponding author.

E-mail addresses: ghrafiee@ut.ac.ir (G. Rafiee), shadir@chalmers.se (S. Rahimi), ivan.mijakovic@chalmers.se (I. Mijakovic).
} 
results suggest that the selected microbiomes allowed for a significant improvement of water quality in a recirculating aquaculture system (RAS).

\section{Introduction}

Water consumption is very high in aquaculture, thus strategies for reusing aquaculture water have a high priority. The basic prerequisite for reusing aquaculture waters is a nitrification treatment (Malone and Pfeiffer, 2006). This process involves a two-step reaction, often catalyzed by aerobic autotrophic microorganisms using carbon dioxide as an energy source (Foesel et al., 2007; Brown et al., 2012). At first, ammonia-oxidizing microorganisms (AOM) oxidize ammonia to hydroxylamine $\left(\mathrm{NH}_{2} \mathrm{OH}\right)$, using the enzyme called ammonia monooxygenase (AMO). This process will be completed by the enzyme called hydroxylamine oxidoreductase, which produces nitrite. In the next step, nitrite-oxidizing bacteria (NOB) will oxidize nitrite to nitrate $\left(\mathrm{NO}^{3-}\right)$, using the enzyme called nitrite oxidoreductase (NOR or NXR) (Limpiyakorn et al., 2011; Spieck and Lipski, 2011a).

Continuous removal of ammonium and nitrite is also required in recirculating aquaculture systems (RAS), and this is achieved by biofilters. Biofilters for water quality improvement are separated from the fish breeding part of RAS (Suurnäkki et al., 2020) and their activities critically depends on the microbial community they contain (Schreier et al., 2010). The activity of AOB and NOB in biofilter communities decreases with temperature reduction (Chen et al., 2006; Urakawa et al., 2008; Veraart et al., 2011). The removal of harmful compounds is optimal at $25^{\circ} \mathrm{C}$ and can be compromised at lower temperatures (below $15^{\circ} \mathrm{C}$ ) (Balmelle et al., 1992; Chen et al., 2006; Alawi et al., 2007; Kim and Lee, 2011). In order for ammonium and nitrite removal to function at lower temperatures, the $\mathrm{AOB}$ and $\mathrm{NOB}$ must adapt their metabolic activity (Berry and Foegeding, 1997; Polissi et al., 2003). Rainbow trout is an example of a species living optimally in cold water $\left(9-15{ }^{\circ} \mathrm{C}\right)$ rearing systems (Urakawa et al., 2008; Neissi et al., 2020). Therefore, microbial adaptation to lower temperatures is necessary in biofilters used in aquatic rearing systems for rainbow trout (Taotao et al., 2015).

Biofilter systems commonly do not operate at maximum efficiency, because the microbial communities present in biofilter systems are natural, and they are rarely supplemented with specific species or engineered (Xing et al., 2020). While the natural microbial communities in biofilters can reduce pollutants such as ammonium or nitrite, they can also be destroyed by chemicals and drugs, such as antibiotics present in RAS (Crawford et al., 2017). Therefore, maintaining the communities of autotrophic AOB and NOB is essential in a RAS system.

Bioaugmentation is a bioremediation strategy related to microorganisms that are supplied to the system and their activities could speed up the elimination of contaminants (Jiao et al., 2009; Salência et al., 2016). Bio-augmentation or microbial enrichment of such microbial communities could be used as an effective strategy for ensuring productive water treatment (Shukla et al., 2020). Microbial enrichment is a procedure for increasing the percentage of a specific microorganism group in the community (Chen et al., 2005). This process is usually performed by providing the nutrients and optimal conditions for the desired microorganisms, thus allowing them to outcompete other species (Kamilova et al., 2005).

The aim of this study was the enrichment of biofilter communities used in rainbow trout RAS with autotrophic AOB and NOB species adapted to low temperatures. Considering the key role of these microorganisms in the nitrification process in biofilter systems, we argue that the adapted and enriched nitrifying microbial community presented in this study could play an important role in the treatment of aquaculture water at low temperatures.

\section{Material and methods}

\subsection{Sampling}

For $\mathrm{AOB}$ and NOB microbiome enrichment, water samples were collected from different water sources in Gothenburg, Sweden artificial lake $\left[57^{\circ} 41^{\prime} 02.6^{\prime \prime} \mathrm{N} \quad 11^{\circ} 56^{\prime} 50.0^{\prime \prime} \mathrm{E}\right] \quad(\mathrm{SDL})$, river $\left[57^{\circ} 41^{\prime} 49.4^{\prime \prime} \mathrm{N}\right.$ $\left.11^{\circ} 55^{\prime} 04.5^{\prime \prime} \mathrm{E}\right]$ (GR), and natural lake $\left[57^{\circ} 40^{\prime} 42.4^{\prime \prime} \mathrm{N} 12^{\circ} 03^{\prime} 25.7^{\prime \prime} \mathrm{E}\right.$ $57^{\circ} 40^{\prime} 42.4^{\prime \prime} \mathrm{N} 12^{\circ} 03^{\prime} 25.7^{\prime \prime} \mathrm{E}$ ] (DL). Additionally, two wastewater samples with high concentration of ammonium (WW1) and nitrite (WW2) were also utilized.

\section{2. $A O B$ and $N O B$ enrichment}

To obtain enriched AOB and NOB microbial communities from the harvested samples, we have used the optimal medium for growing AOB and NOB bacteria. $3 \mathrm{ml}$ of water samples (SDL, GR, DL, WW1 and WW2) were inoculated in $47 \mathrm{ml}$ of $\mathrm{AOB}$ liquid medium with ammonium ( $\mathrm{pH}$ 7.2) (Verhagen and Laanbroek, 1991; Bollmann et al., 2011) and $47 \mathrm{ml}$ of NOB liquid medium with nitrite $(\mathrm{pH}$ 8.4-8.6) (Hankinson and Schmidt, 1988; Spieck and Lipski, 2011b). Samples were grown in 100 $\mathrm{ml}$ sterile flasks at room temperature (RT, $21 \pm 2{ }^{\circ} \mathrm{C}$ ) at $170 \mathrm{rpm}$ (all flasks were covered by aluminum foil). To continuously supply the alkalinity for the optimal growth of AOB and NOB bacteria, bromothymol blue was added to the medium (Lipponen et al., 2002) to monitor the color change corresponding to $\mathrm{pH}$. Thus, when the medium color turned to yellow, the $\mathrm{pH}$ was adjusted.

Samples were transferred to a fresh culture medium after $80 \%$ consumption of ammonium or nitrite (approximately after 2 weeks). We have repeated this procedure three times in a consecutive manner. Next, the cultures were grown in a AOB and NOB fresh culture medium for 2 weeks. Ammonium and nitrite concentration were measured in the sampels at the starting point and after 2 weeks, using Hach spectrophotometer DR 3900 (according to the manufacturer's protocol: LCK340 kits for nitrate assay, LCK303 for ammonium assay and LCK339 for nitrite assay). The samples showing significantly reduced level of ammonium and increased level of nitrite compared to starting point (GR, SDL, and WW1) were selected as the communities with the highest ammonium removal activity. The samples showing significantly reduced level of nitrite and increased level of nitrate compared to starting point (DL and WW2) were selected as the communities with the highest nitrite removal activity.

\subsection{Microbiome identification by $16 S$ rRNA sequencing}

The genomic DNA of selected microbiomes was extracted using the Ultra clean Qiagen kit according to the manufacturer's protocol. The 16 $S$ rRNA fragments were amplified using a thermocycler (c1000 touch thermal cycler, BioRad, USA) after preparation with primstar PCR kit, using the following primers: $5^{\prime}$-AGA GTT TGA TCC TGG CTC AG-3' and 5'-GGT TAC CTT GTT ACG ACT T-3' (Table 1). The PCR amplified products were purified using GeneJET PCR Purification Kit (Thermo Scientific). The size and quality of $16 \mathrm{~S}$ rRNA fragments (expected size $1.5 \mathrm{~kb}$ ) were checked by agarose gel electrophoresis (Supplemental Fig. 1). The amplified $16 \mathrm{~S}$ rRNA fragments of selected microbiomes were sequenced at the Novo Nordisk Foundation Center for Biosustainability, Technical University of Denmark. $2 \times 300$ bp pooling library samples endured paired-end sequencing production until $\approx 40,000$ paired-end reads. The data were analyzed using the ezbiocloud bioinformatics platform (bacterial and archaeal community analysis, https://www.ezbiocloud.net/) (Yoon et al., 2017). 


\subsection{Temperature adaptation}

After screening for samples with the best ammonium and nitrite removal activities, various temperatures of 9,15 , RT and $30{ }^{\circ} \mathrm{C}$ were used for temperature adaptation of selected microbial communities. 3 $\mathrm{ml}$ of each selected sample was transferred to $250 \mathrm{ml}$ flasks containing $97 \mathrm{ml}$ of either AOB or NOB culture medium. Samples were grown at different temperatures: $9{ }^{\circ} \mathrm{C}, 15^{\circ} \mathrm{C}$, RT, and $30{ }^{\circ} \mathrm{C}$. The ammonium and nitrite concentrations in the culture samples were determined weekly. When nearby $80 \%$ of the ammonium and nitrite were consumed, $3 \mathrm{ml}$ of the culture was transferred to a fresh either AOB or NOB culture medium. It was repeated three times for a period of one and half months (Verhagen and Laanbroek, 1991; Bollmann et al., 2011).

\subsection{Quantitative PCR ( $q-P C R)$}

Specific q-PCR primers for AMO and NXR genes were designed for AOB (Nitrosmonas oligotropha) and NOB (Nitrobacter winogradskyi) group strains, respectively. Furthermore, a constitutively expressed gene (16 S rRNA gene) was used for selected strains as an internal reference (Supplementary Table S1).

RNA was extracted from microbial community samples adapted to different temperatures and stored at $-80{ }^{\circ} \mathrm{C}$. cDNA was synthesized from the isolated RNA. The expression of AMO and NXR genes was analyzed by q-PCR according to Rahimi et al., (2020) (Rahimi et al., 2020). The relative values of gene expression were assessed using Agilent Technologies Stratagene Mx30005 P and were calculated according to the manufacturer's instructions (Chen et al., 2005).

\subsection{SEM microscopy analysis}

For SEM analysis, $15 \mathrm{ml}$ of microbial cultures were centrifuged at $6000 \mathrm{rpm}$ for $3 \mathrm{~min}$. The microbial cells were then fixed overnight using $3 \%$ of glutaraldehyde. The fixed cells were dehydrated using graded series of ethanol $(40 \%, 50 \%, 60 \%, 70 \%, 80 \%, 90 \%$, and $100 \%)$ for 10 min each. Thin films were prepared by using dehydrated samples on cover glass and dried for $24 \mathrm{~h}$ at RT. The dried samples were then sputter coated with gold $(5 \mathrm{~nm})$ before imaging. SEM imaging was performed with JEOL JSM 6301 F (Carl Zeiss AG, Jena, Germany).

\subsection{Ammonium and nitrite measurments in biofilter water in the presence of $A O B-G R$ and NOB-WW2 microbiomes}

Water from a RAS trout biofilter system (nexus 220 filtration system, $\mathrm{pH}=7.8$; ammonium $=0.5 \mathrm{mg} / \mathrm{ml}$; Nitrite $=0.4 \mathrm{mg} / \mathrm{ml}$ and temperature $=11^{\circ} \mathrm{C}$ ) was obtained from the Department of Environmental Sciences, University of Gothenburg, Sweden. Ammonium and nitrite concentrations were increased by addition of ammonium sulphate and sodium nitrite stock solutions to the biofilter water. $3 \mathrm{ml}$ of the AOB-GR microbiome $\left(9{ }^{\circ} \mathrm{C}\right.$ - and $15{ }^{\circ} \mathrm{C}$-adapted) were mixed with $47 \mathrm{ml}$ low ammonium concentration water (biofilter water) $(0.5 \mathrm{mg} / \mathrm{ml}), 47 \mathrm{ml}$ medium ammonium concentration water $(5 \mathrm{mg} / \mathrm{ml})$, and $47 \mathrm{ml}$ high ammonium concentration water $(35 \mathrm{mg} / \mathrm{ml}) .3 \mathrm{ml}$ of the NOB-WW2 microbiome $\left(9{ }^{\circ} \mathrm{C}\right.$ - and $15{ }^{\circ} \mathrm{C}$-adapted) were mixed with $47 \mathrm{ml}$ low nitrite concentration water $(0.4 \mathrm{mg} / \mathrm{ml})$ (biofilter water), $47 \mathrm{ml}$ medium nitrite concentration water $(4 \mathrm{mg} / \mathrm{ml})$, and $47 \mathrm{ml}$ high nitrite concentration water $(8 \mathrm{mg} / \mathrm{ml})$. In a refrigerated incubator, 3 replicates of each mixture were grown at $9{ }^{\circ} \mathrm{C}$ and $15^{\circ} \mathrm{C}$ at $170 \mathrm{rpm}$. To evaluate the effect of selected microbiomes and comparing their performance in a natural RAS biofilter water, negative control groups was used that include high, medium, and low ammonium/nitrite concentration waters without adding the selected microbiomes.

\subsection{Statistical analysis}

The normality of data was evaluated by the Kolmogorov-Smirnov analysis test. One way ANOVA was used for comparing data means. The significance level among different treatments was determined by the Tukey test, at $5 \%$ level. Statistical analysis was performed by SPSS 17 software and the graphs were drawn by Microsoft excel 2019.

\section{Results}

\subsection{The environmental water samples enriched with $A O B$ and $N O B$} microbial communities effectively remove ammonium and nitrite

Different water sources have different limnological conditions (from eutrophic to oligotrophic) that support growth of different bacterial species (Biddanda et al., 2001; Karydis et al., 2009). Therefore, to achieve microbial communities with the highest ammonium and nitrite removal activity, different water sources in Gothenburg, Sweden, were selected. These included an artificial lake (SDL), a river (GR), a natural lake (DL), and two different types of wastewater (WW1 and WW2). The ammonium, nitrite, and nitrate concentrations, $\mathrm{pH}$ and temperature indices were measured in the samples collected from these water sources (Fig. 1a).

When anaerobically treated sewage sludge is dewatered, reject water is generated that contains high concentrations of ammonium (Meyer and Wilderer, 2004). The concentration of ammonium and nitrate was highest in raw reject water sample which we refer to as WW1. We also used the reject water treated with nitritation (ammonia oxidation to nitrite) and anammox (Du et al., 2015), which contains high concentration of nitrite and is referred to as WW2 (Fig. 1a). By contrast, the lowest concentrations of ammonium and nitrate were related to DL, and the lowest concentration of nitrite was related to SDL.

Our results indicated that the ammonium removal and nitrite production activities were high in GR, WW1, and SDL samples (Fig. 1b), whereas the WW2 and DL exhibited higher nitrite removal and nitrate production (Fig. 1c). Considering that the selected microbial communities were related to the municipal sewage, river, and lakes, the possibility of enriching autotrophic $\mathrm{AOB}$ and NOB bacteria from the selected sources seemed logical (Watson, 1965; Suwa et al., 1994; Utåker et al., 1995). Therefore, GR, WW1, and SDL with the highest ammonium removal performance were selected for further experiments as AOB-enriched microbial communities, and WW2 and DL samples with the highest nitrite removal performance were selected as NOB-enriched microbial communities. To increase the efficiency of these communities at various temperatures $\left(9,15, \mathrm{RT}\right.$ and $\left.30^{\circ} \mathrm{C}\right)$, temperature adaptation was performed at the next stage.

\subsection{Temperature-adapted $A O B$ and $N O B$ microbiomes are able to remove} ammonium and nitrite at different temperatures

Given wide range of temperatures used in aquaculture (cold and

Table 1

Primers and PCR conditions for amplification of $16 \mathrm{~S}$ rRNA in enriched microbiomes.

\begin{tabular}{|c|c|c|c|c|c|c|c|c|}
\hline \multirow[t]{2}{*}{ Primer } & \multirow[t]{2}{*}{ Sequence } & \multicolumn{7}{|l|}{ PCR conditions } \\
\hline & & Denaturation & & Annealing & & Extension & & Number of cycles \\
\hline \multirow[t]{2}{*}{$27 \mathrm{~F}$} & 5'-AGAGTTTGATCC TGG CTC AG-3' & & & & & & & \\
\hline & & Temperature $\left({ }^{\circ} \mathrm{C}\right)$ & Time (s) & Temperature $\left({ }^{\circ} \mathrm{C}\right)$ & Time (s) & Temperature $\left({ }^{\circ} \mathrm{C}\right)$ & Time (s) & 27 \\
\hline $1492 \mathrm{R}$ & 5'-GGTTACCTTGTT ACG ACT T-3' & 95 & 30 & 50 & 30 & 72 & 60 & \\
\hline
\end{tabular}


a)

\begin{tabular}{cccccc}
\hline & WW1 & WW2 & DL & SDL & GR \\
\hline $\mathrm{pH}$ & 7.5 & 8.23 & 7.4 & 7.6 & 7.3 \\
$\mathrm{NH}_{4}-\mathrm{N}(\mathrm{mg} / \mathrm{l})$ & 1006 & 22.4 & 0.006 & 0.051 & 0.135 \\
$\mathrm{NO}_{2}-\mathrm{N}(\mathrm{mg} / \mathrm{l})$ & 1.9 & 76.6 & 0.025 & 0.024 & 0.026 \\
$\mathrm{NO}_{3}-\mathrm{N}(\mathrm{mg} / \mathrm{l})$ & 82 & 2.2 & 0.053 & 0.352 & 0.079 \\
\hline
\end{tabular}

b)

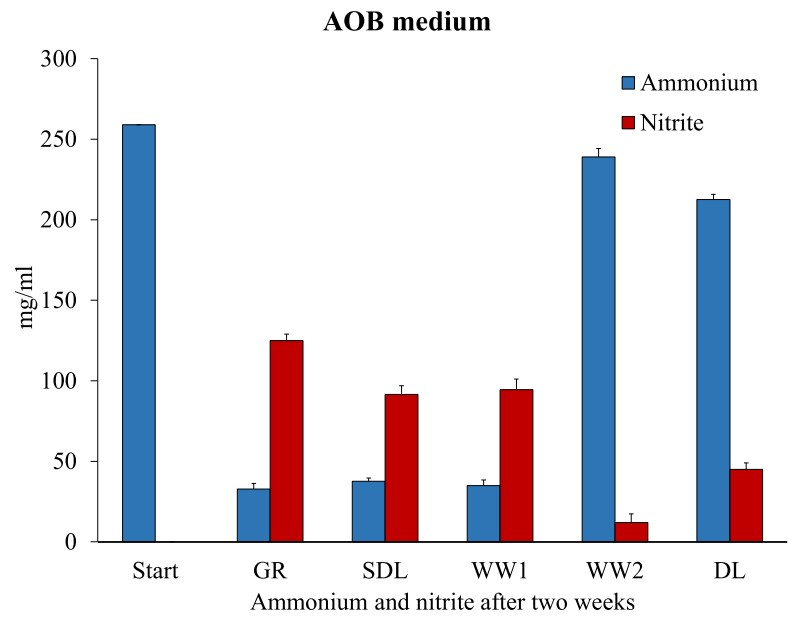

c)

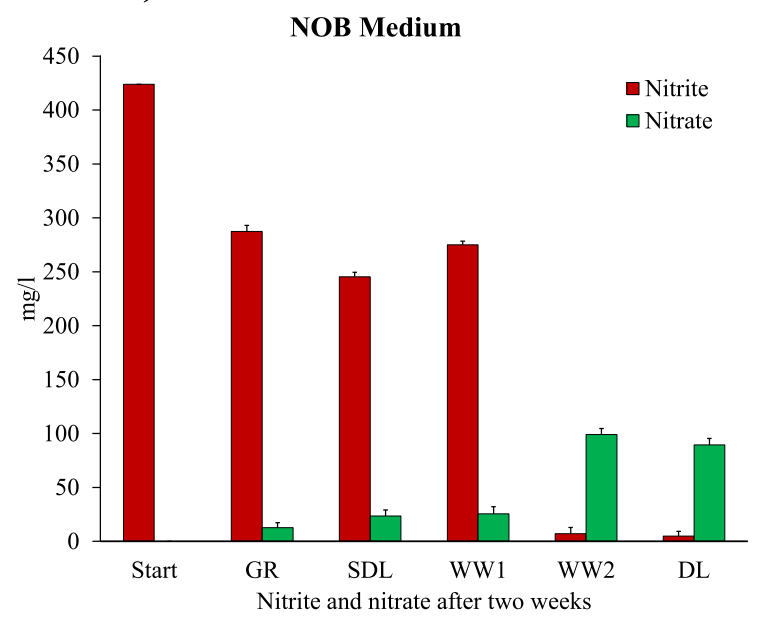

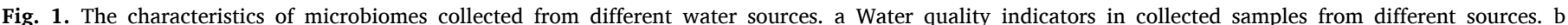

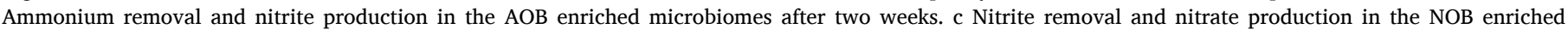
microbiomes after two weeks.

warm water fishies), we have selected various temperatures of 9, 15, RT and $30{ }^{\circ} \mathrm{C}$ for temperature adaptation of selected microbial communities. We have also evaluated the ammonium and nitrite removal activity of selected microbiomes based on reducing the concentration of ammonium (Fig. 2a-g) and nitrite (Fig. 3a-g) at different temperatures: $9{ }^{\circ} \mathrm{C}, 15{ }^{\circ} \mathrm{C}$, RT, and $30^{\circ} \mathrm{C}$. RT was overall the optimal temperature for ammonium removal. At this temperature, the GR sample was able to completely remove ammonium after $216 \mathrm{~h}$ (Fig. 2b). SDL and WW1 microbiomes where somewhat slower, reaching complete ammonium removal after $288 \mathrm{~h}$ and $480 \mathrm{~h}$, respectively. The ammonium removal activity was reduced in all microbiomes at $30^{\circ} \mathrm{C}$ compared to RT, but the highest ammonium removal rate was still found in the GR sample, completely removing ammonium after $288 \mathrm{~h}$ (Fig. 2a). At $15{ }^{\circ} \mathrm{C}$, the ammonium removal was further reduced. The GR sample was still the best performer, requiring $384 \mathrm{~h}$ for complete removal (Fig. 2c). Decreasing the temperature to $9{ }^{\circ} \mathrm{C}$ dramatically decreased ammonium removal of all sample, but the GR was still the best performer (Fig. 2d). Due to the poor performance of the WW1 microbiome in ammonium removal at all tested temperatures, it was excluded from further experiments (Fig. 2a-d).

The NOB-enriched microbiomes (WW2 and DL) exhibited the best nitrite removal rate at $30{ }^{\circ} \mathrm{C}$ (Fig. 3a-d). At this temperature, nitrite was completely removed by the WW2 sample after $144 \mathrm{~h}$ (Fig. 3a). Nitrite removal decreased in both samples with decreasing temperatures (Fig. 3b-d). The WW2 sample consistently showed a higher rate of nitrite removal at all temperatures (Fig. 3a-d).

In order to correlate metabolic activity of ammonium and nitrite removal with expression of key genes at population level, we investigated the expression of key genes AMO and NXR, involved these respective processes. Highest expression levels of AMO and NXR were observed in GR and WW2 samples, respectively (Figs. 2e and 3e). The expression of both AMO and NXR was highest in the temperature range of $25-30{ }^{\circ} \mathrm{C}$. This result was consistent with the highest ammonium and nitrite removal activity of GR and WW2 at RT and $30{ }^{\circ} \mathrm{C}$, respectively.

\subsection{Key nitrifying bacteria are present in selected $A O B$ and $N O B$ microbiomes}

Although a biofilter system is separate module of the RAS during fish farming, it is nevertheless important to ensure that there are no pathogenic bacteria (especially primary pathogens) in the microbial community before its addition to the biofilter section (Menanteau-Ledouble et al., 2020). Therefore, our GR and WW2 microbiomes underwent identification of bacterial strains. The results showed that Nitrosmonas oligotropha (21.6\% of all DNA reads in the metagenome) and Nitrobacter winogradskyi (6.1\% of all DNA reads in the metagenome) were the dominant species in the GR and WW2 microbiomes, respectively (Figs. 2f and 3f). These species are known to be involved in the nitrification process (Vanparys et al., 2007; Sayavedra-Soto et al., 2015). With such high prevalence of $N$. oligotropha and $N$. winogradskyi, it should be possible to visualize these species using the SEM microscopic observation of the bacterial communities. In the GR sample, we were able to identify many rod-shaped bacteria. It is plausible to presume that these bacteria with rod-shaped morphology might be Nitrosomonas oligotropha based on the morphology described by Watson and Mandel (1971) (Fig. 2g). Similarly, in the WW2 sample, we were able to identify cells corresponding to the general description of the genus Nitrobacter (Fig. 3g). The bacteria pathogens of aquatic animals and humans that are commonly encountered in RAS was previously listed (Timpe and Runyon, 1954; Von Graevenitz, 1977; Vine et al., 2004; Noga, 2010; Defoirdt et al., 2011; Blandford et al., 2018; Ina-Salwany et al., 2019). Presence of these bacteria was investigated in the microbial communities of GR and WW2 samples. According to our results, there were no pathogenic bacteria in the GR and WW2 communities. 
a)

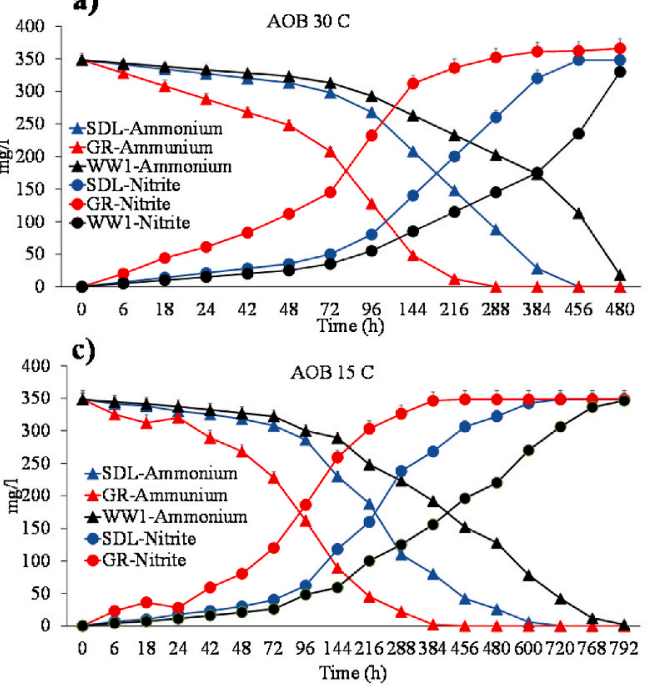

b)

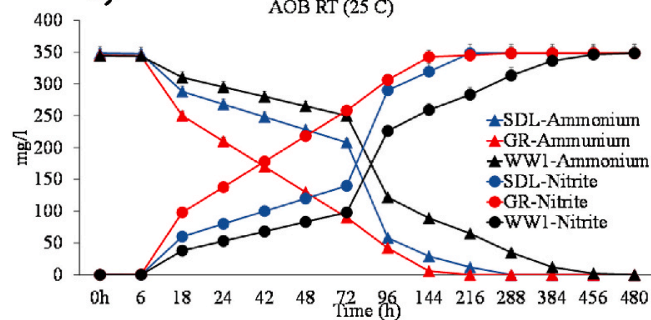

d)

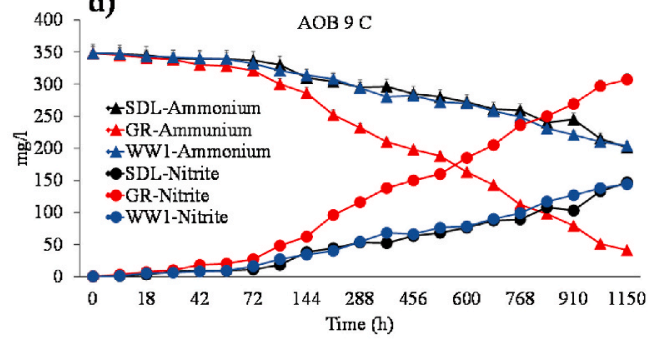

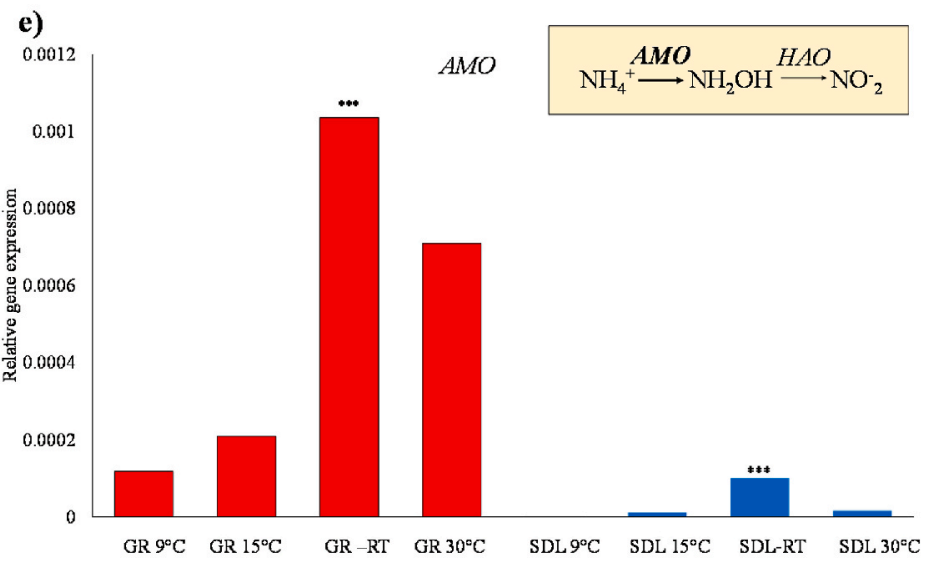

f)

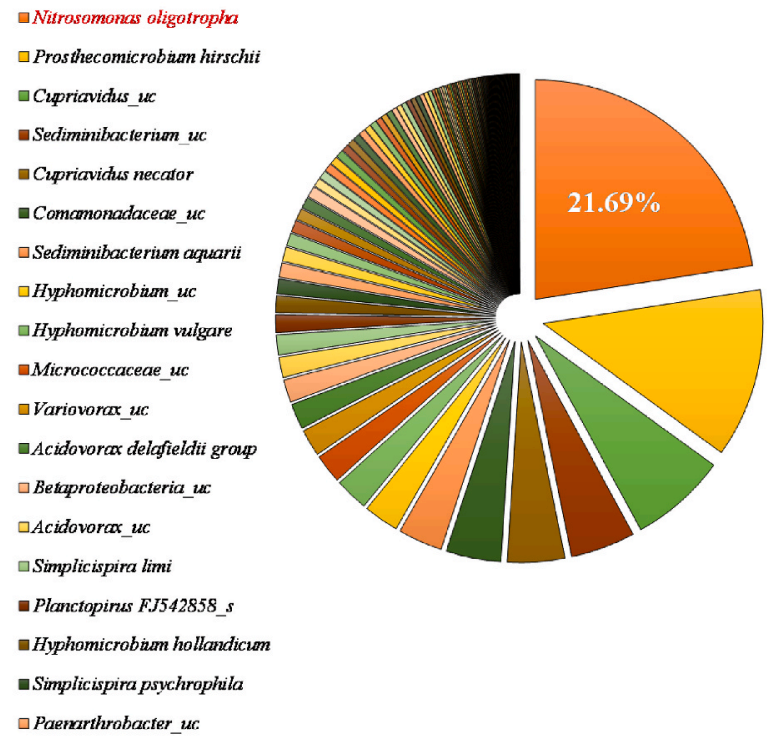

g)

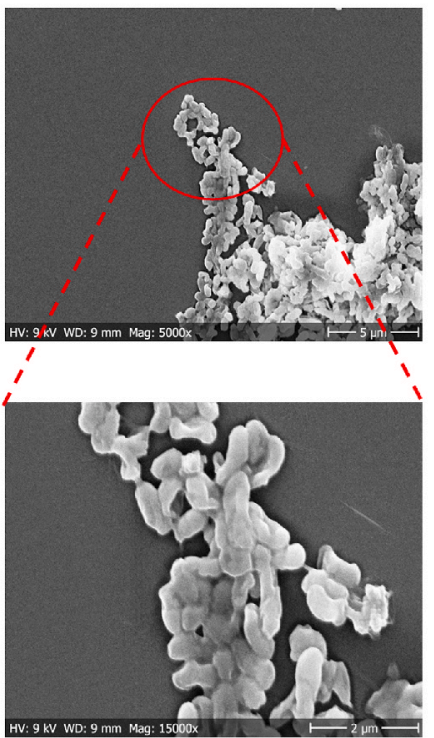

Fig. 2. Ammonium removal and nitrite production using: a $30{ }^{\circ} \mathrm{C}$-adapted $\mathrm{AOB}$ microbiomes, b temperature-adapted $\mathrm{AOB}$ microbiomes, c $15{ }^{\circ} \mathrm{C}$-adapted $\mathrm{AOB}$ microbiomes, and d $9{ }^{\circ} \mathrm{C}$-adapted $\mathrm{AOB}$ microbiomes. e Ammonia monooxygenase (AMO) gene expression in the different temperature-adapted AOB microbiomes. $\mathrm{f}$ Bacterial population (species) in GR microbiome g Microscopic observation of Nitrosomonas oligotropha in GR microbiome. 
a)

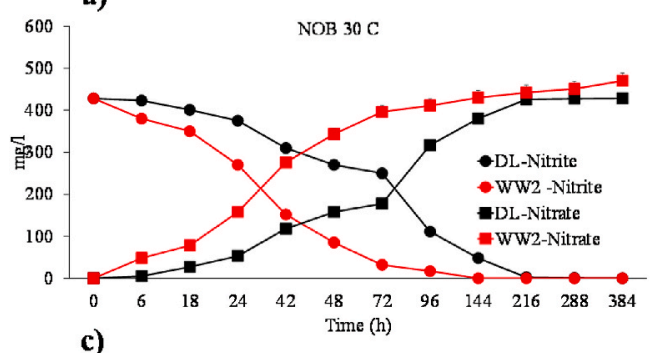

c)

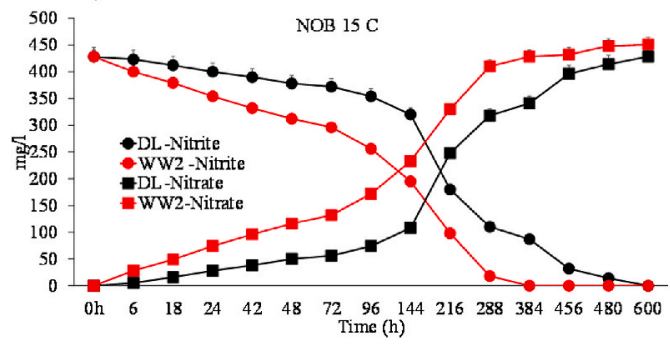

e)

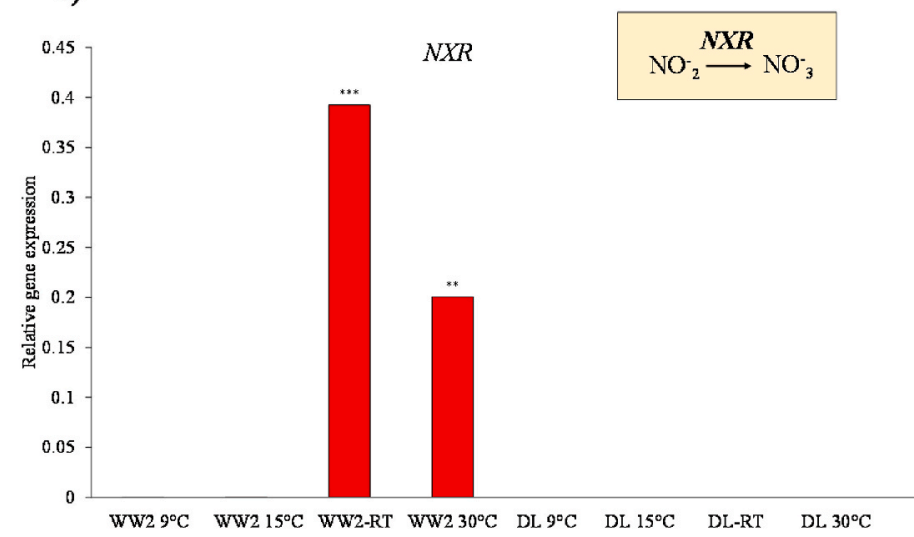

f)

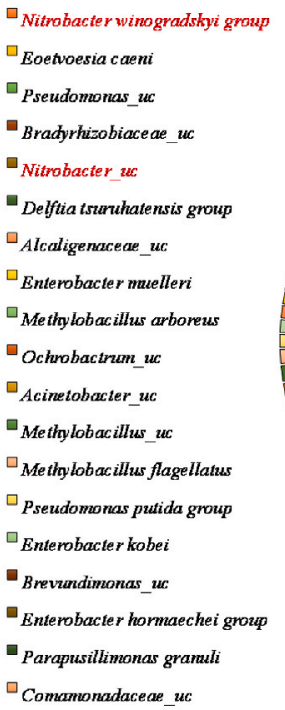

$\square_{\text {Nitrobacter winogradshyi group }}$

Eoetwoesia caen

Nitrobacier

- Delftia tsumuhatensis group

$\square_{\text {Alcaligenace ae } u c}$

${ }_{\text {Enterobacter mueller }}$

$\square_{\text {Me thylobacillus arboreus }}$

$\square$ Methylobacillus flagellatus

$\square_{\text {sseudomonas putida group }}$

$\square$ Enterobacter hormaechei group

${ }$ Comamonadaceae_uc b)

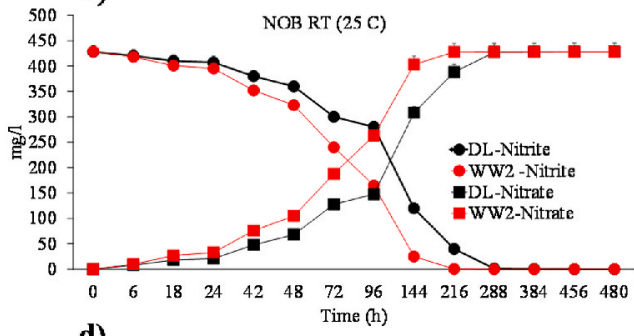

d)

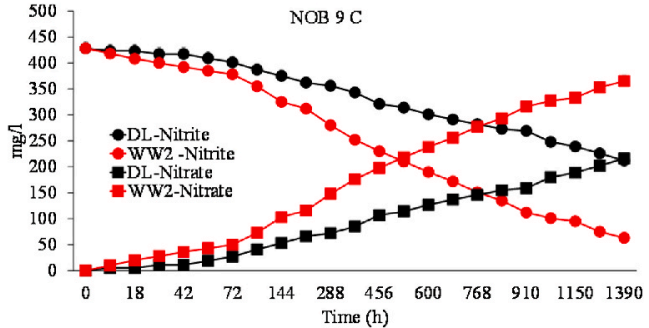

g)

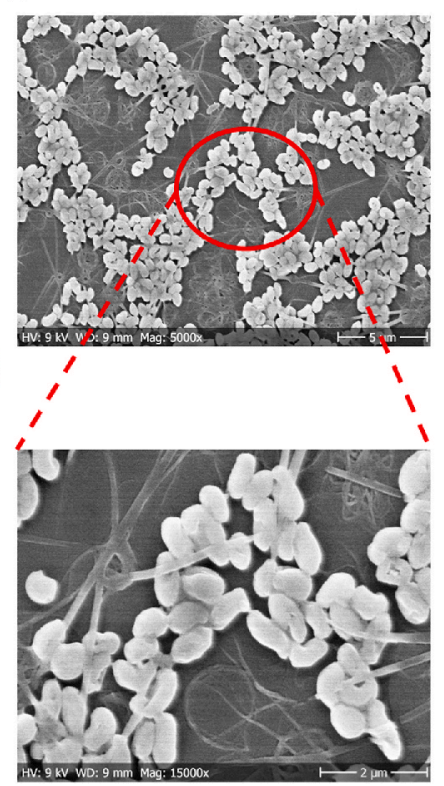

Fig. 3. Nitrite removal and nitrate production using a $30{ }^{\circ} \mathrm{C}$-adapted NOB microbiomes, b temperature-adapted NOB microbiomes, c $15{ }^{\circ} \mathrm{C}$-adapted NOB microbiomes, and d $9{ }^{\circ} \mathrm{C}$-adapted NOB microbiomes. e Nitrite oxidoreductase (NXR) gene expression in the different temperature-adapted AOB microbiomes. f Bacterial population (species) in WW2 microbiome g Microscopic observation of WW2 microbiome. 
3.4. GR and WW2 microbiomes efficiently remove ammonium and nitrite from biofilter water at 9 and $15{ }^{\circ} \mathrm{C}$

To test the activity of the selected microbiomes (GR and WW2) for use on RAS biofilters, they were further tested in biofilter water samples with different concentrations of ammonium $(0.5,5$, and $35 \mathrm{mg} / \mathrm{ml})$ and nitrite $(0.4,4$, and $8 \mathrm{mg} / \mathrm{ml})$. The ammonium and nitrite removal activities of GR and WW2 were investigated in these water samples at 9 and $15^{\circ} \mathrm{C}$ (Fig. 4a-f, Fig. 5a-f). The results showed that the respective ammonium and nitrite removal activity of the GR and WW2 samples was higher than the negative control groups (natural biofilter water) at all tested doses of ammonium and nitrite at the selected temperatures (9 and $15^{\circ} \mathrm{C}$ ) (Figs. $4 \mathrm{~g}$ and $5 \mathrm{~g}$ ). The ammonium and nitrite removal activity of our microbial communities was expectedly slower at $9{ }^{\circ} \mathrm{C}$ than at $15{ }^{\circ} \mathrm{C}$. The slow removal activities at $9{ }^{\circ} \mathrm{C}$ was not specific to our microbial communities, as it was also observed in the negative control group (Fig. 4b, d, Fig. 4f, Fig. 5b, Fig. 5d, f). In spite of slow removal activities at $9{ }^{\circ} \mathrm{C}$, the removal rate of GR and WW2 was much higher than that of the negative control sample, that is commonly found in RAS systems. The ammonium removal by GR was improved by $288 \%$ over the control (Fig. 4g), and nitrite removal by WW2 was improved by $181 \%$ over the control microbial community (Fig. $5 \mathrm{~g}$ ). The effect of ammonium and nitrite concentrations in biofilter water on ammonium and nitrite removal activity was shown in Fig. 6. The optimum ammonium concentration for ammonium removal activity of AOB microbial community (GR) was $5 \mathrm{mg} / \mathrm{ml}$ in cold conditions $\left(9\right.$ and $15{ }^{\circ} \mathrm{C}$ ) and even the activity was more pronounced at $9{ }^{\circ} \mathrm{C}$. However in case of nitrite removal activity, the optimum nitrite concentration for nitrite removal activity of NOB microbial community (WW2) was $8 \mathrm{mg} / \mathrm{ml}$ in cold conditions ( 9 and $15{ }^{\circ} \mathrm{C}$ ) and similar to AOB community, the nitrite removal activity was highly significant at $9{ }^{\circ} \mathrm{C}$.
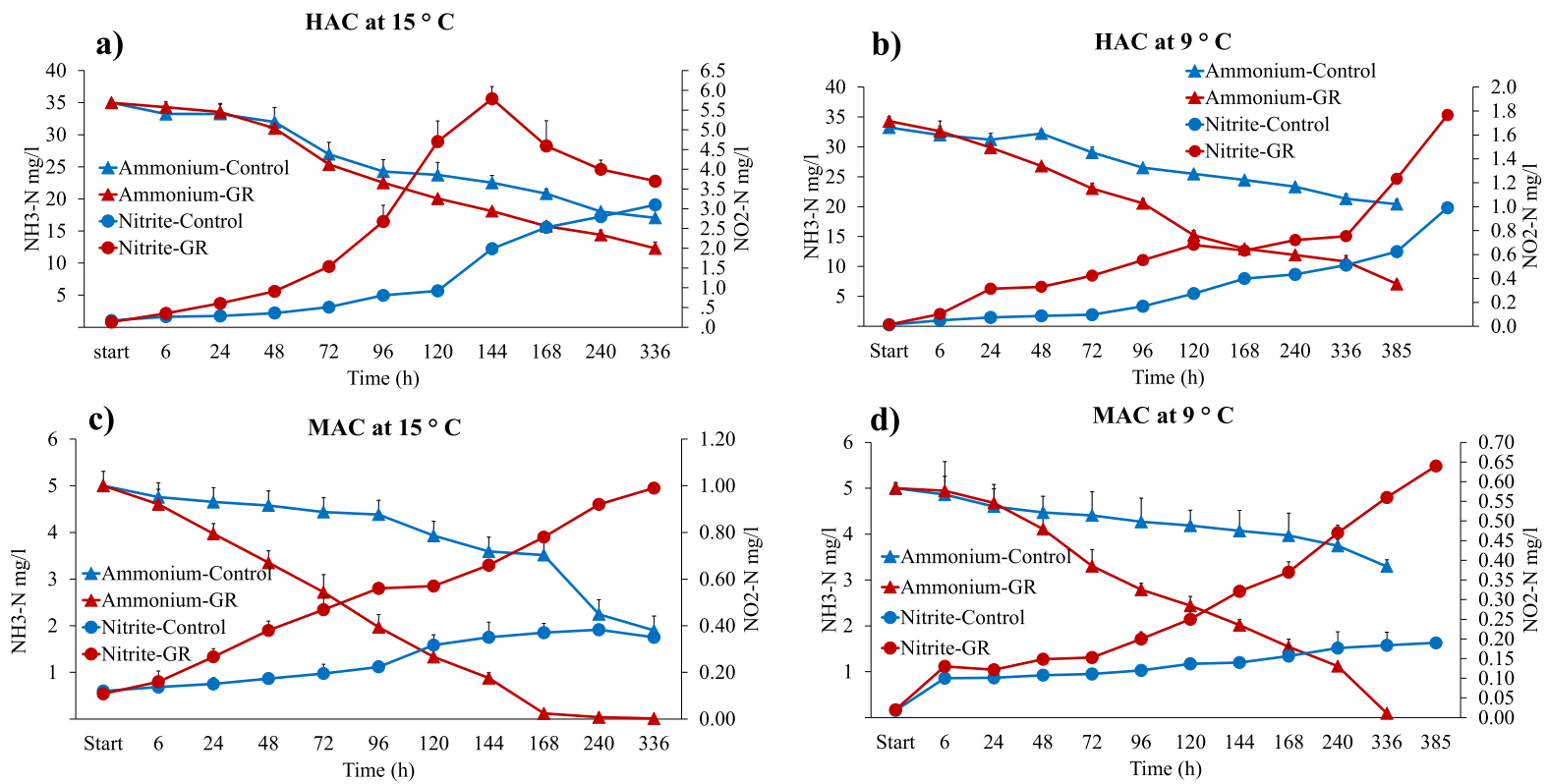

e)

LAC at $15^{\circ} \mathrm{C}$

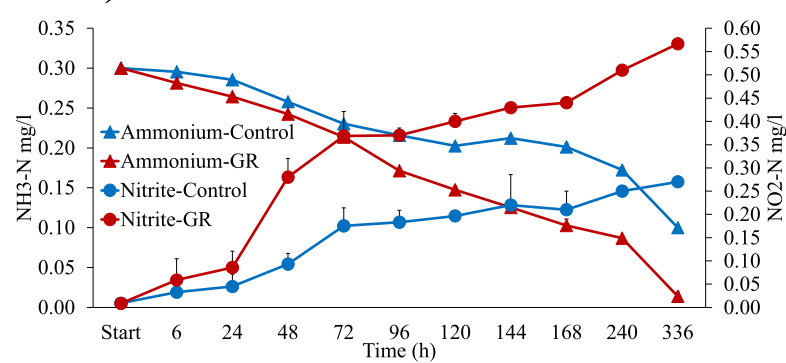

f)

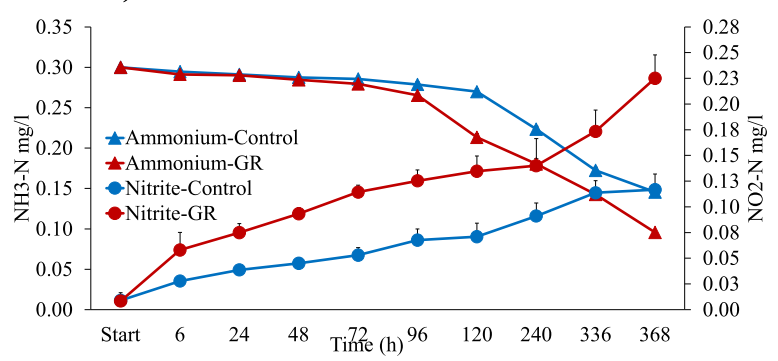

g) $\square$ Control $\$$ GR-Microbiome

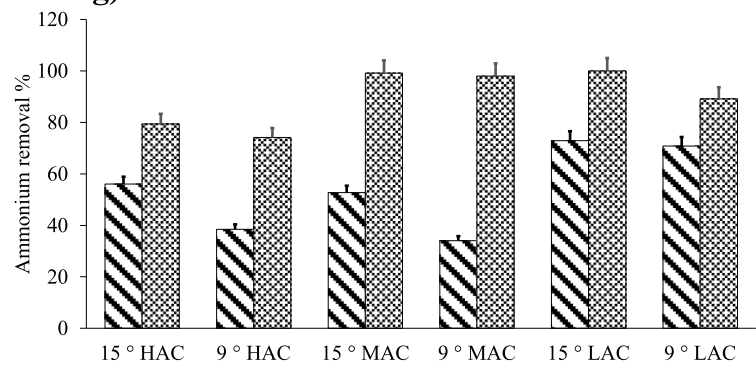

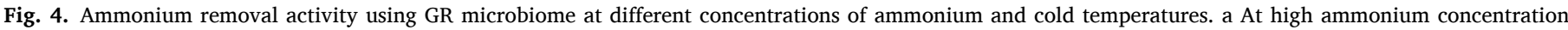

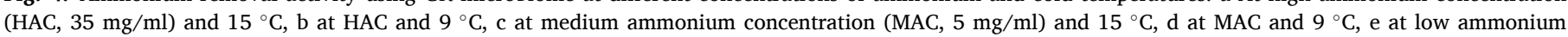

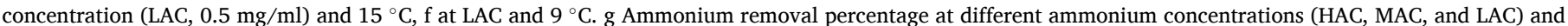
temperatures ( 9 and $15^{\circ} \mathrm{C}$ ) using GR microbiome. 
a)

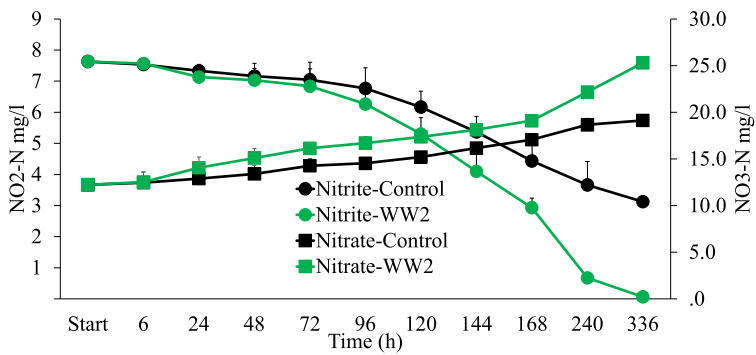

c)

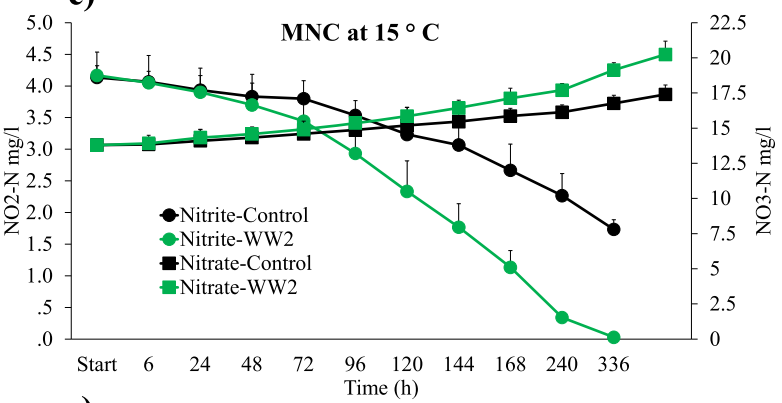

e)

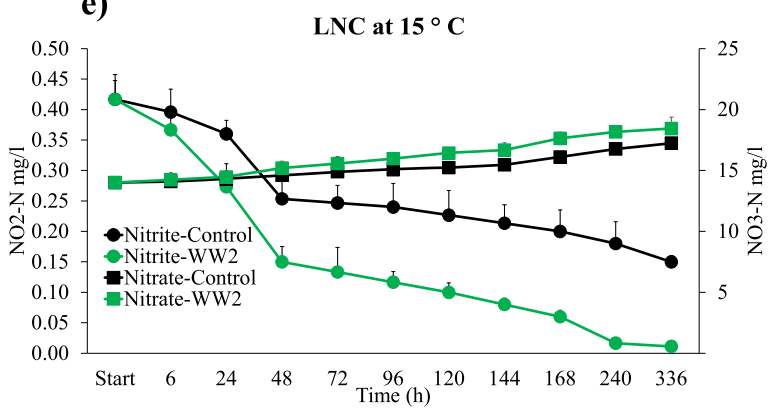

b) $\quad \mathrm{HNC}$ at $9^{\circ} \mathrm{C}$

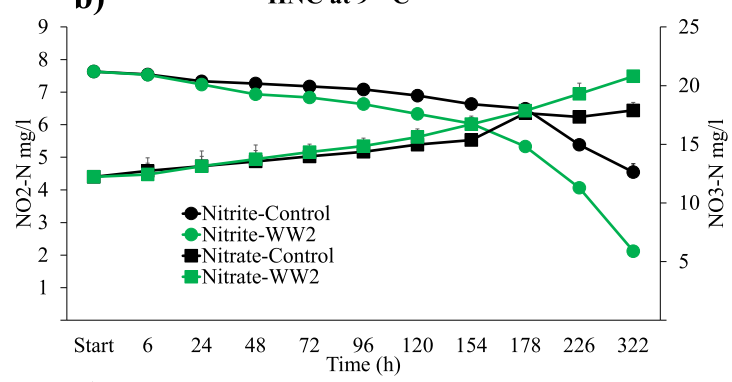

d)

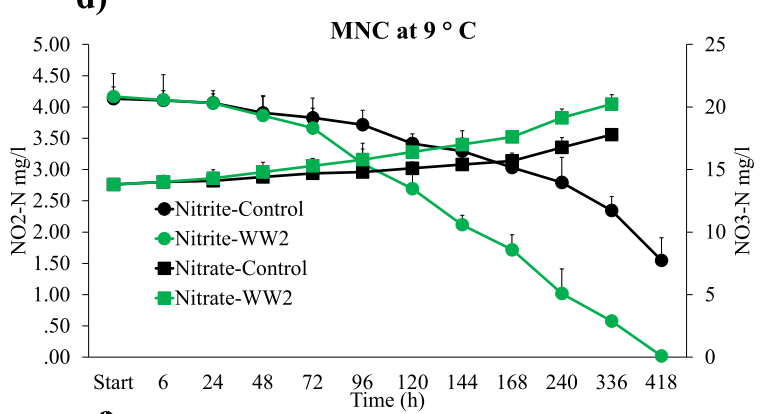

f)

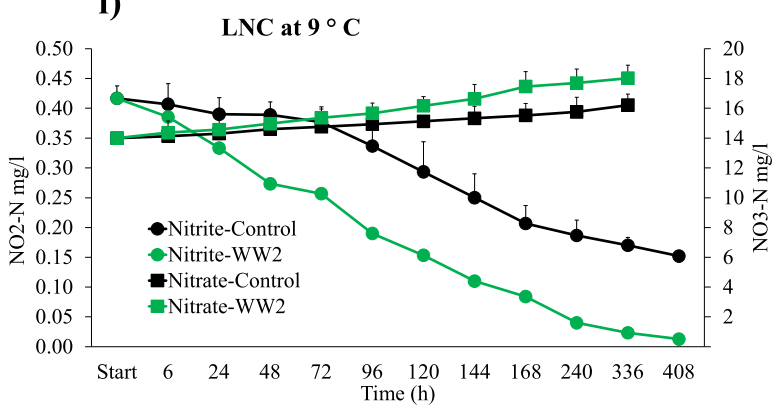

g) $\quad$ Control $\&$ WW2-Microbiome

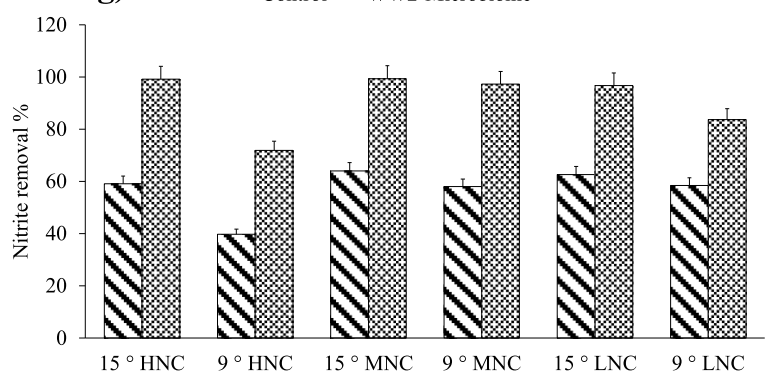

Fig. 5. Nitrite removal activity using WW2 microbiome at different concentrations of nitrite and cold temperatures. a At high nitrite concentration (HNC, $8 \mathrm{mg} / \mathrm{ml}$ ) and $15{ }^{\circ} \mathrm{C}$, b at HNC and $9{ }^{\circ} \mathrm{C}$, c at medium nitrite concentration (MNC, $4 \mathrm{mg} / \mathrm{ml}$ ) and $15{ }^{\circ} \mathrm{C}, \mathrm{d}$ at MNC and $9{ }^{\circ} \mathrm{C}$, e at low nitrite concentration (LNC $0.4 \mathrm{mg} / \mathrm{ml}$ ) and $15^{\circ} \mathrm{C}$, f at LNC and $9{ }^{\circ} \mathrm{C}$. g Nitrite removal percentage at different concentrations (HNC, MNC, and LNC) and temperatures $\left(9\right.$ and $\left.15{ }^{\circ} \mathrm{C}\right)$ using WW2 microbiome.

\section{Discussion}

Bioremediation has emerged as a sustainable strategy to improve the water quality of aquaculture effluents and reduce potential environmental pollution. In this regard, a set of microorganisms can be beneficial to increase the rate of polutant removal. There are several recent studies showing the effectiveness of aquatic wastewater treatment by using microbial assemblies (John et al., 2020; hui Liang et al., 2021; Patil et al., 2021). However, most of these studies used the hetertrophic bacteria as the bioaugmentation agent. Given high efficiency of autotrophic bacteria to remove ammonium and nitrite, the application of enriched microbiome containing a significant percentage of autotrophic $\mathrm{AOB}$ and NOB bacteria can be beneficial.

In this study, we focused on removal of ammonium and nitrite in RAS wastewater using microbial communities dominated by autotrophic $\mathrm{AOB}$ and NOB bacteria collected from different water sources.

Intensive rearing of aquatic animals includes fish, crustaceans and bivalves that grow densely in the systems with recirculating water. Increase of animal density in water results in the higher concentration of pollutants (ammonium and nitrite). The biofilters of these systems, whose microorganisms are colonized, have a certain capacity for water treatment, pollutants removal and water reuse, and it is still challenging to maintain the hygienic conditions suitable for breeding (Khater, 2012; De Prisco, 2020). If a solution is found to more efficiently eliminate the pollutants, then the capacity of the system can be increased, which would make the process more economical and more sustainable (Tomasso, 1994; Van Wyk and Scarpa, 1999; Fotedar, 2016). Nitrification in RAS biofilters is driven mostly by the nitrifying bacteria (Losordo et al., 


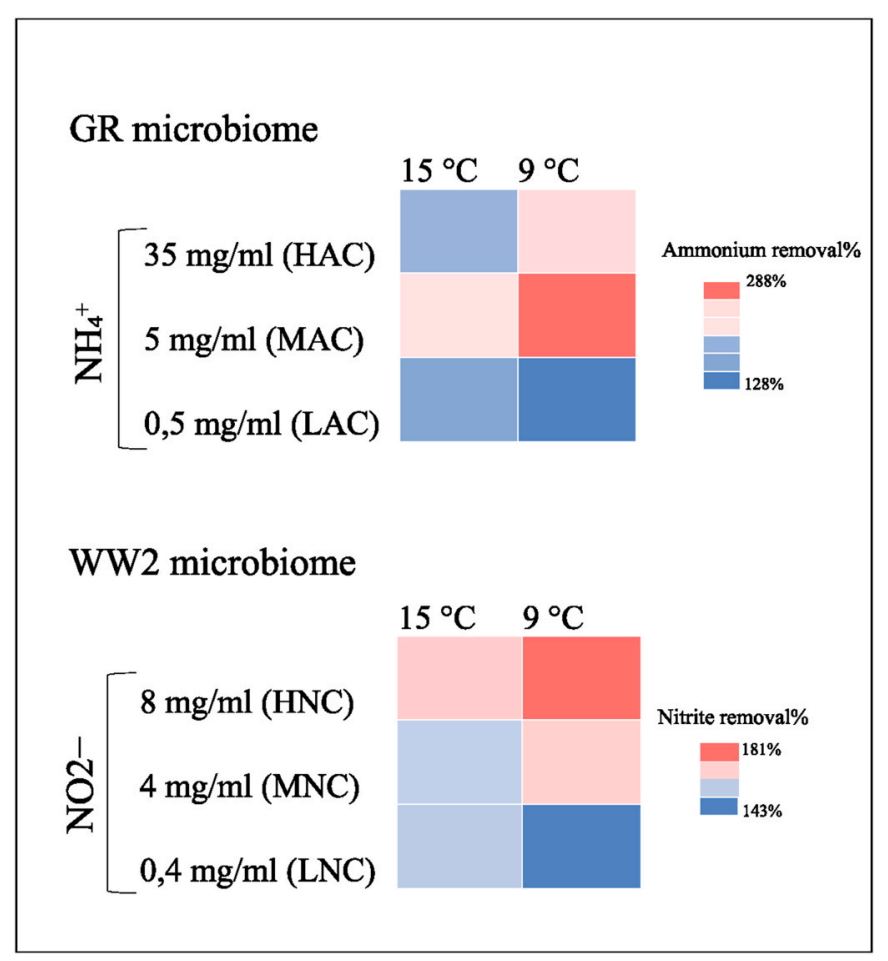

Fig. 6. Heatmap of improvement of ammonium and nitrite removal percentage by GR and WW2 microbiomes compared with the negative control group at different concentrations of ammonium (HAC, MAC, and LAC) and nitrite (HNC, MNC, and LNC) in cold conditions ( 9 and $15^{\circ} \mathrm{C}$ ).

1998; Ebeling and Timmons, 2010). These bacteria mostly comprise slow-growing species of the genera Nitrospira, Nitrobacter, Nitrosomonas, Nitrococcus, and Nitrosococcus (Grady and Lim, 1980; Prosser, 1990). When a RAS system is getting started, it is possible to add a slow growing microbial community to the system without fish (Ebeling and Timmons, 2010; Wongkiew et al., 2017). Thus, a community enriched with suitable nitrifying bacteria could be added to a starting RAS to ensure optimal operation of the biofilter (Urakawa et al., 2008). Metagenomic and metatranscriptomic techniques are helpful for investigating microbial communities and enable taxonomic analysis and classification of bacterial varieties (Godde et al., 2019). In this study, we showed that the GR microbial community, selected for its AOB activity and enriched with $N$. oligotropha, could be used for effective ammonium removal at both high and low temperatures in a trout aquaculture biofilter water system. $N$. oligotropha is a Gram-negative, rod-shaped species with aerobic metabolism (Wahman et al., 2011). In our selected NOB-enriched community, the WW2 sample, $N$. winogradskyi was found as the dominant denitrifier. $N$. winogradskyi is a Gram-negative bacterium that plays a key role in the nitrogen cycle by converting nitrite to nitrate as the end product of ammonium oxidation in nitrification process (Starkenburg et al., 2006).

During fish farming, RAS system moves towards the nitrificant bacteria that have adapted to the system. Biofilters play an essential role in these systems. Proteobacteria sp, Bacteriodetes sp, Nitrospirae sp, Planctomycetes sp, Rhizobiaceae, and Chloroflexi sp that Nitrosomonas sp, Nitrospira sp. and Nitrobacter sp. are the most common microbial communities in biofilter systems (Bartelme et al., 2017; Brailo et al., 2019; Hüpeden et al., 2020). In order to compare the performance of our selected microbiomes with the natural colonized AOB and NOB bacteria, the temperature-adapted GR and WW2 microbiomes were added to the RAS biofilter water. The results demonstrated the positive effect of selected microbiomes containing $N$. oligotropha and $N$. winogradskyi on nitrite and nitrate production in biofilter water at low temperatures ( 9 and $15{ }^{\circ} \mathrm{C}$ ), respectively.
It has been shown that $N$. oligotropha isolated from Austin Lake used mainly the AMO enzyme for ammonium removal (Wahman et al., 2011). Hence, we confirmed that the AMO gene was highly expressed in the GR microbiome, corresponding to peak ammonium removal activity (Fig. 2e). The negative effect of lower temperatures on ammonium removal was accompanied by lower expression of the AMO gene (Fig. 2e). Nitrite gets reduced to nitrate by NXR enzyme, whose differential expression was detected in the WW2 microbiome (Fig. 3e). NXR expression correlated very well with the nitrite removal activity of the WW2 community (Fig. 3).

\section{Conclusions}

In this study we report a strategy for bio-augmentation of RAS biofilters enriched with autotrophic $\mathrm{AOB}$ and NOB bacteria. Using the enriched microbial community GR, we achieved a $288 \%$ improvement in ammonium removal over the commonly used communities in biofilters at $9{ }^{\circ} \mathrm{C}$ (Fig. 6). Similarly, the enriched community WW2 improved nitrite removal by $181 \%$ compared to the commonly used communities in biofilters at $9{ }^{\circ} \mathrm{C} \mathrm{(Fig.} \mathrm{6).} \mathrm{It} \mathrm{is} \mathrm{important} \mathrm{to} \mathrm{emphasize}$ that no pathogenic bacteria were identified in the GR and WW2 microbiomes, making them eminently suitable for application in low temperature RAS for trout breeding. We would therefore propose bioaugmentation with GR and WW2 as a safe and effective improvement to the standard procedures in RAS for trout breeding. However, the performance and stability of these microbiomes need to be studied for long time operation in the fish farming system in the future. Furthermore, the surface colonization of these microbiomes needs to be studied using different biofilters, in order to optimize colonization and maximize their effectiveness.

\section{Authors' contributions}

Alireza Neissi, Shadi Rahimi, Gholamreza Rafiee, Hamid Farahmand and Ivan Mijakovic designed the project. Alireza Neissi and Shadi Rahimi performed the laboratory works. Alireza Neissi and Shadi Rahimi and Ivan Mijakovic performed library preparation, sequencing, and metagenomics analysis. Alireza Neissi and Shadi Rahimi prepared microbiome samples and photographed with SEM. All authors contributed to the preparation of the manuscript.

\section{Declaration of competing interest}

The authors declare that they have no known competing financial interests or personal relationships that could have appeared to influence the work reported in this paper.

\section{Acknowledgements}

We thank James Hinchcliffe from University of Gothenburg, Department of Biological \& Environmental Sciences for providing access to their RAS biofilter water distribution systems. Leila Keshavarz assisted in water sample collection. This study was supported by the University of Tehran, Department of Fisheries Sciences; Iran National Science Foundation; a grant from the from the Novo Nordisk Foundation (grant NNF10CC1016517); and a grant from ÅForsk grant [19-508].

\section{Appendix A. Supplementary data}

Supplementary data to this article can be found online at https://doi. org/10.1016/j.chemosphere.2022.133811.

\section{References}

Alawi, M., Lipski, A., Sanders, T., Spieck, E., 2007. Cultivation of a novel cold-adapted nitrite oxidizing betaproteobacterium from the Siberian Arctic. ISME J. 1, 256-264. 
Balmelle, B., Nguyen, K., Capdeville, B., Cornier, J., Deguin, A., 1992. Study of factors controlling nitrite build-up in biological processes for water nitrification. Water Sci. Technol. 26, 1017-1025.

Bartelme, R.P., McLellan, S.L., Newton, R.J., 2017. Freshwater recirculating aquaculture system operations drive biofilter bacterial community shifts around a stable nitrifying consortium of ammonia-oxidizing archaea and comammox Nitrospira. Front. Microbiol. 8, 101.

Berry, E.D., Foegeding, P.M., 1997. Cold temperature adaptation and growth of microorganisms. J. Food Protect. 60, 1583-1594.

Biddanda, B., Ogdahl, M., Cotner, J., 2001. Dominance of bacterial metabolism in oligotrophic relative to eutrophic waters. Limnol. Oceanogr. 46, 730-739.

Blandford, M.I., Taylor-Brown, A., Schlacher, T.A., Nowak, B., Polkinghorne, A., 2018. Epitheliocystis in fish: an emerging aquaculture disease with a global impact. Transboundary emerging dis. 65, 1436-1446.

Bollmann, A., French, E., Laanbroek, H.J., 2011. Isolation, cultivation, and characterization of ammonia-oxidizing bacteria and archaea adapted to low ammonium concentrations. In: Methods in Enzymology. Elsevier, pp. 55-88.

Brailo, M., Schreier, H.J., McDonald, R., Maršić-Lučić, J., Gavrilović, A., Pećarević, M., Jug-Dujaković, J., 2019. Bacterial community analysis of marine recirculating aquaculture system bioreactors for complete nitrogen removal established from a commercial inoculum. Aquaculture 503, 198-206.

Brown, M.N., Briones, A., Diana, J., Raskin, L., 2012. Ammonia-oxidizing archaea and nitrite-oxidizing nitrospiras in the biofilter of a shrimp recirculating aquaculture system. FEMS Microbiol. Ecol. 83, 17-25.

Chen, S., Ling, J., Blancheton, J.-P., 2006. Nitrification kinetics of biofilm as affected by water quality factors. Aquacult. Eng. 34, 179-197.

Chen, Y.S., Yanagida, F., Shinohara, T., 2005. Isolation and identification of lactic acid bacteria from soil using an enrichment procedure. Lett. Appl. Microbiol. 40, 195-200.

Crawford, G., Hurrel, P., Paroschy, K., Pereira, C., 2017. Pharmaceuticals and Other Endocrine Disrupting Compounds in Natural Water Systems. Muskoka Watershed Council, Bracebridge.

De Prisco, J.A., 2020. An Investigation of Some Key Physico-Chemical Water Quality Parameters of an Integrated Multi-Trophic Aquaculture (IMTA) System Operating Recirculation Methodology in the Western Cape of South Africa. Faculty of Science.

Defoirdt, T., Sorgeloos, P., Bossier, P., 2011. Alternatives to antibiotics for the control of bacterial disease in aquaculture. Curr. Opin. Microbiol. 14, 251-258.

Du, R., Peng, Y., Cao, S., Wang, S., Wu, C., 2015. Advanced nitrogen removal from wastewater by combining anammox with partial denitrification. Bioresour. Technol. 179, 497-504.

Ebeling, J.M., Timmons, M.B., 2010. Recirculating Aquaculture. Cayuga Aqua Ventures.

Foesel, B.U., Gieseke, A., Schwermer, C., Stief, P., Koch, L., Cytryn, E., De La Torré, J.R., Van Rijn, J., Minz, D., Drake, H.L., 2007. Nitrosomonas Nm143-like ammonia oxidizers and Nitrospira marina-like nitrite oxidizers dominate the nitrifier community in a marine aquaculture biofilm. FEMS Microbiol. Ecol. 63, 192-204.

Fotedar, R., 2016. Water quality, growth and stress responses of juvenile barramundi (Lates calcarifer Bloch), reared at four different densities in integrated recirculating aquaculture systems. Aquaculture 458, 113-120.

Godde, k., Joyce, A., Kotzen, B., Burnell, G., 2019. Aquaponics Food Production Systems: Combined Aquaculture and Hydroponic Production Technologies for the Future. Springer Nature.

Grady, C., Lim, H., 1980. Continuous Stirred Tank Reactors. Biological Wastewater Treatment, Theory and Application.

Hankinson, T., Schmidt, E., 1988. An acidophilic and a neutrophilic Nitrobacter strain isolated from the numerically predominant nitrite-oxidizing population of an acid forest soil. Appl. Environ. Microbiol. 54, 1536-1540.

hui Liang, D., Hu, Y., Liang, D., Chenga, J., Chena, Y., 2021. Bioaugmentation of moving bed biofilm reactor (MBBR) with achromobacter JL9 for enhanced sulfamethoxazole (SMX) degradation in aquaculture wastewater. Ecotoxicol. Environ. Saf. 207, 111258.

Hüpeden, J., Wemheuer, B., Indenbirken, D., Schulz, C., Spieck, E., 2020. Taxonomic and functional profiling of nitrifying biofilms in freshwater, brackish and marine RAS biofilters. Aquacult. Eng. 90, 102094.

Ina-Salwany, M., Al-saari, N., Mohamad, A., Mursidi, F.A., Mohd-Aris, A., Amal, M., Kasai, H., Mino, S., Sawabe, T., Zamri-Saad, M., 2019. Vibriosis in fish: a review on disease development and prevention. J. Aquat. Anim. Health 31, 3-22.

Jiao, Y., Jin, W., Zhao, Q., Zhang, G., Yan, Y., Wan, J., 2009. Transformation of nitrogen and distribution of nitrogen-related bacteria in a polluted urban stream. Water Sci. Technol. 60, 1597-1605.

John, E.M., Krishnapriya, K., Sankar, T., 2020. Treatment of ammonia and nitrite in aquaculture wastewater by an assembled bacterial consortium. Aquaculture 526, 735390.

Kamilova, F., Validov, S., Azarova, T., Mulders, I., Lugtenberg, B., 2005. Enrichment for enhanced competitive plant root tip colonizers selects for a new class of biocontrol bacteria. Environ. Microbiol. 7, 1809-1817.

Karydis, M., University of the Aegean, L.I.D.o.E.S., University of the Aegean, L.I.D.o.E.S., 2009. Eutrophication assessment of coastal waters based on indicators: a literature review. In: Proceedings of the International Conference on Environmental Science and Technology. University of the Aegean, Chania(Greece).

Khater, E., 2012. Simulation Model for Design and Management of Water Recirculating Systems in Aquaculture. Agricultural Engineering Department, Faculty of Agriculture, Moshtohor, Benha University, Moshtohor, Egypt.

Kim, J., Lee, B., 2011. Effect of temperature on nitrogen removal and microbial community composition in nitrifying biofilm reactors. In: Proceedings of 2011 6th International Forum on Strategic Technology. IEEE, pp. 476-479.
Limpiyakorn, T., Sonthiphand, P., Rongsayamanont, C., Polprasert, C., 2011. Abundance of amoA genes of ammonia-oxidizing archaea and bacteria in activated sludge of full-scale wastewater treatment plants. Bioresour. Technol. 102, 3694-3701.

Lipponen, M.T., Suutari, M.H., Martikainen, P.J., 2002. Occurrence of nitrifying bacteria and nitrification in Finnish drinking water distribution systems. Water Res. 36, 4319-4329.

Losordo, T.M., Masser, M.P., Rakocy, J., 1998. Recirculating aquaculture tank production systems. In: Overview of Critical Considerations, vol. 451. SRAC Publication.

Malone, R.F., Pfeiffer, T.J., 2006. Rating fixed film nitrifying biofilters used in recirculating aquaculture systems. Aquacult. Eng. 34, 389-402.

Menanteau-Ledouble, S., Gonçalves, R.A., El-Matbouli, M., 2020. Feed supplementation with a commercially available probiotic solution does not alter the composition of the microbiome in the biofilters of recirculating aquaculture systems. Pathogens 9 , 830.

Meyer, S., Wilderer, P., 2004. Reject water: treating of process water in large wastewater treatment plants in Germany-a case study. J. Environ. Sci. Health, Part A 39, 1645-1654.

Neissi, A., Rafiee, G., Farahmand, H., Rahimi, S., Mijakovic, I., 2020. Cold-resistant heterotrophic ammonium and nitrite-removing bacteria improve aquaculture conditions of rainbow trout (Oncorhynchus mykiss). Microb. Ecol. 1-12.

Noga, E.J., 2010. Fish Disease: Diagnosis and Treatment. John Wiley \& Sons.

Patil, P.K., Antony, L., Avunje, S., Viswanathan, B., Lalitha, N., Jangam, A.K., Kumar, D., Solanki, H.G., Reddy, M.A., Alavandi, S.V., 2021. Bioaugmentation with nitrifying and denitrifying microbial consortia for mitigation of nitrogenous metabolites in shrimp ponds. Aquaculture 541, 736819.

Polissi, A., De Laurentis, W., Zangrossi, S., Briani, F., Longhi, V., Pesole, G., Dehò, G., 2003. Changes in Escherichia coli transcriptome during acclimatization at low temperature. Res. Microbiol. 154, 573-580.

Prosser, J.I., 1990. Autotrophic nitrification in bacteria. Adv. Microb. Physiol. 30 $125-181$.

Rahimi, S., Modin, O., Roshanzamir, F., Neissi, A., Alam, S.S., Seelbinder, B., Pandit, S., Shi, L., Mijakovic, I., 2020. Co-culturing Bacillus subtilis and wastewater microbial community in a bio-electrochemical system enhances denitrification and butyrate formation. Chem. Eng. J. 397, 125437.

Salência, H., Mouriño, J., Ferreira, G., Arantes, R., Ubert, M., Lapa, K., Seiffert, W., 2016. A bioaugmentation agent in super intensive marine shrimp farming system with zero water exchange. J. Aquacult. Res. Dev. 7.

Sayavedra-Soto, L., Ferrell, R., Dobie, M., Mellbye, B., Chaplen, F., Buchanan, A., Chang, J., Bottomley, P., Arp, D., 2015. Nitrobacter winogradskyi transcriptomic response to low and high ammonium concentrations. FEMS Microbiol. Lett. 362, $1-7$.

Schreier, H.J., Mirzoyan, N., Saito, K., 2010. Microbial diversity of biological filters in recirculating aquaculture systems. Curr. Opin. Biotechnol. 21, 318-325.

Shukla, S., Rajta, A., Setia, H., Bhatia, R., 2020. Simultaneous nitrification-denitrification by phosphate accumulating microorganisms. World J. Microbiol. Biotechnol. 36, 1-17.

Spieck, E., Lipski, A., 2011a. 5 cultivation, growth physiology, and chemotaxonomy of nitrite-oxidizing bacteria. Methods Enzymol. 486, 109-130.

Spieck, E., Lipski, A., 2011b. Cultivation, growth physiology, and chemotaxonomy of nitrite-oxidizing bacteria. In: Methods in Enzymology. Elsevier, pp. 109-130.

Starkenburg, S.R., Chain, P.S., Sayavedra-Soto, L.A., Hauser, L., Land, M.L., Larimer, F. W., Malfatti, S.A., Klotz, M.G., Bottomley, P.J., Arp, D.J., 2006. Genome sequence of the chemolithoautotrophic nitrite-oxidizing bacterium Nitrobacter winogradskyi Nb255. Appl. Environ. Microbiol. 72, 2050-2063.

Suurnäkki, S., Pulkkinen, J.T., Lindholm-Lehto, P.C., Tiirola, M., Aalto, S.L., 2020. The effect of peracetic acid on microbial community, water quality, nitrification and rainbow trout (Oncorhynchus mykiss) performance in recirculating aquaculture systems. Aquaculture 516, 734534.

Suwa, Y., Imamura, Y., Suzuki, T., Tashiro, T., Urushigawa, Y., 1994. Ammonia-oxidizing bacteria with different sensitivities to (NH4) $2 \mathrm{SO} 4$ in activated sludges. Water Res. 28, 1523-1532.

Taotao, Z., Dong, L., Huiping, Z., Shuibo, X., Wenxin, Q., Yingjiu, L., Jie, Z., 2015. Nitrogen removal efficiency and microbial community analysis of ANAMMOX biofilter at ambient temperature. Water Sci. Technol. 71, 725-733.

Timpe, A., Runyon, E.H., 1954. The relationship of "atypical" acid-fast bacteria to human disease: a preliminary report. J. Lab. Clin. Med. 44, 202-209.

Tomasso, J., 1994. Toxicity of nitrogenous wastes to aquaculture animals. Rev. Fish. Sci. 2, 291-314.

Urakawa, H., Tajima, Y., Numata, Y., Tsuneda, S., 2008. Low temperature decreases the phylogenetic diversity of ammonia-oxidizing archaea and bacteria in aquarium biofiltration systems. Appl. Environ. Microbiol. 74, 894-900.

Utåker, J.B., Bakken, L., Jiang, Q.Q., Nes, I.F., 1995. Phylogenetic analysis of seven new isolates of ammonia-oxidizing bacteria based on 16S rRNA gene sequences. Syst. Appl. Microbiol. 18, 549-559.

Van Wyk, P., Scarpa, J., 1999. Water quality requirements and management. In: Farming Marine Shrimp in Recirculating Freshwater Systems, pp. 141-162.

Vanparys, B., Spieck, E., Heylen, K., Wittebolle, L., Geets, J., Boon, N., De Vos, P., 2007. The phylogeny of the genus Nitrobacter based on comparative rep-PCR, 16S rRNA and nitrite oxidoreductase gene sequence analysis. Syst. Appl. Microbiol. 30, 297-308.

Veraart, A.J., De Klein, J.J., Scheffer, M., 2011. Warming can boost denitrification disproportionately due to altered oxygen dynamics. PLoS One 6, e18508.

Verhagen, F.J., Laanbroek, H.J., 1991. Competition for ammonium between nitrifying and heterotrophic bacteria in dual energy-limited chemostats. Appl. Environ. Microbiol. 57, 3255-3263. 
Vine, N., Leukes, W., Kaiser, H., Daya, S., Baxter, J., Hecht, T., 2004. Competition for attachment of aquaculture candidate probiotic and pathogenic bacteria on fish intestinal mucus. J. Fish. Dis. 27, 319-326.

Von Graevenitz, A., 1977. The role of opportunistic bacteria in human disease. Annu. Rev. Microbiol. 31, 447-471.

Wahman, D.G., Kirisits, M.J., Katz, L.E., Speitel, G.E., 2011. Ammonia-oxidizing bacteria in biofilters removing trihalomethanes are related to Nitrosomonas oligotropha. Appl. Environ. Microbiol. 77, 2537-2540.

Watson, S.W., 1965. Characteristics of a marine nitrifying bacterium. Nitrosocystis oceanus sp. N. 1. Limnol. Oceanography 10, R274-R289.
Watson, S.W., Mandel, M., 1971. Comparison of the morphology and deoxyribonucleic acid composition of 27 strains of nitrifying bacteria. J. Bacteriol. 107, 563-569. Wongkiew, S., Hu, Z., Chandran, K., Lee, J.W., Khanal, S.K., 2017. Nitrogen transformations in aquaponic systems: a review. Aquacult. Eng. 76, 9-19.

Xing, X., Li, T., Bi, Z., Qi, P., Li, Z., Wang, H., Lyu, L., Gao, Y., Hu, C., 2020. Efficient removal of disinfection by-products precursors and inhibition of bacterial detachment by strong interaction of EPS with coconut shell activated carbon in ozone/biofiltration. J. Hazard Mater. 392, 122077.

Yoon, S.-H., Ha, S.-M., Kwon, S., Lim, J., Kim, Y., Seo, H., Chun, J., 2017. Introducing EzBioCloud: a taxonomically united database of $16 \mathrm{~S}$ rRNA gene sequences and whole-genome assemblies. Int. J. Syst. Evol. Microbiol. 67, 1613. 